\title{
SISTEM PENDUKUNG KEPUTUSAN SELEKSI SISWA KELAS UNGULAN DI SMP NEGERI 7 MALANG
}

\author{
Sandi Fajri Ramadani ${ }^{1}$, Ekojono ${ }^{2}$, Nurudi Santoso ${ }^{3}$ \\ Program Studi Teknik Informatika, Jurusan Teknologi Informasi, Politeknik Negeri Malang \\ 1.
}

\begin{abstract}
Abstrak
Proses seleksi siswa kelas unggulan merupakan peranan penting dalam membangun suatu kelas unggulan, Untuk menghasilkan peserta didik dalam kelas unggulan di perlukan penilaian secara spesifik, Akan tetapi seleksi siswa kelas unggulan yang terjadi saat ini di SMP Negeri 7 Malang masih secara manual. Metode yang digunakan pada sistem pendukung keputusan ini adalah metode TOPSIS (Technique for Order Preference by Similarity to Ideal Solution).Metode TOPSIS merupakan salah satu metode pengambilan keputusan untuk menentukan pilihan terbaik dari kriteria tertentu.Dalam proses seleksi kelas unggulan terdapat beberapa nilai kritria untuk setiap siswa yang dinilai langsung oleh guru pengajar, dimana pada kriteria tersebut terdiri dari nialai akademik, Prestasi, Sanksi, Absensi, Nilai Intelektual dan Kepribadian. Nilai-nilai tersebut diolah menggunakan metode TOPSIyang nantinya akan menghasilkan beberapa nilai akhir dari tiap alternatif yang akan diurutkan berdasarkan nilai tertinggi. Hasil dari penelitian ini siswaakan mendapatkan rekomendasi untuk kelas unggulan berdasarkan hasil nilai-nilai siswa yang telah diolah menggunakan metode TOPSIS.
\end{abstract}

Kata kunci : Sistem Pendukung Keputusan, Kelas Unggulan, TOPSIS

\section{Pendahuluan}

Kelas Unggulan adalah kelas yang diikuti oleh sejumlah siswa yang unggul dalam dua ranah penilaian dengan kecerdasan di atas rata-rata yang dikelompokkan secara khusus. Pengelompokan ini dimaksudkan untuk membina siswa dalam mengembangkan kecerdasan, kemampuan, keterampilan, dan potensinya seoptimal mungkin sehingga memilki pengetahuan, keterampilan, dan sikap yang terbaik sebagaimana semangat konsep wawasan unggulan adalah melalui program kelas unggulan. Hal itu mengacu pada Keputusan Menteri Pendidikan dan Kebudayaan Nomor 0487/U/1992, pasal 15 yaitu penerapan wawasan keunggulan melalui program khusus, program kelas khusus, dan program pendidikan khusus, yang merefleksikan pendidikan keunggulan.

SMP Negeri 7 Malang memiliki suatu program unggulan yang selama ini menjadi peranan penting dalam mutu pembelajaran siswa unggulan yang dapat bersaing di era global pendidikan yaitu kelas unggulan, Seleksi siswa kelas unggulan dilaksanakan pada setiap tahun, dimana seleksi kelas unggulan itu sendiri dikonsentrasikan untuk siswa kelas VII yang nantiknya akan naik ke kelas VIII yang di seleksi seacara langsung oleh wali kelas. Calon siswa seleksi kelas unggulan di peroleh dari setiap kelas VII dengan kuota siswa dari setiap kelas semua disamaratakan maka dari setiap kelas VII akan diperoleh beberapa siswa yang akan masuk kelas unggulan .Akan tetapi pada seleksi siswa untuk kelas unggulan saat ini masihkurang memuaskan karena penilaian yang digunakan untuk seleksi siswa kelas unggulan hanya berpedoman pada nilai akademik siswa, karena nilai akademik yang baik tidak dapat menjamin siswa tersebut akan menjadi siswa berprestasi dan unggulan jika nilai intelektual dan kepribadian siswa sangat buruk. Maka dari itu penilaian seleksi kelas unggulan ini berpedoman pada nilai akademik, prestasi, sanksi, absensi, nilai intelektual dan nilai kepribadian siswa.

\section{Tinjauan Pustaka}

\subsection{Sistem Pendukung Keputusan}

SPK adalah sistem informasi berbasis komputer interaktif dengan koleksi terorganisir dari model, orang, prosedur, software, database, telekomunikasi, dan perangkat, yang membantu para pengambil keputusan untuk memecahkan terstruktur atau semi-terstruktur masalah bisnis (Tripathi, 2011)

\subsection{Kelas Unggulan}

Kelas Unggulan adalah kelas yang diikuti oleh sejumlah siswa yang unggul dalam tiga ranah penilaian dengan kecerdasan di atas rata-rata yang dikelompokkan secara khusus. 


\subsection{TOPSIS}

TOPSIS adalah salah satu metode pengambilan keputusan multikriteria yang pertama kali diperkenalkan oleh Yoon dan Hwang pada tahun 1981. TOPSIS menggunakan prinsip bahwa alternatif yang terpilih harus mempunyai jarak terdekat dari solusi ideal positif dan terjauh dari solusi ideal negatif

Adapun langkah-langkah algoritma dari TOPSIS ini adalah sebagai berikut (Indira, 2012) :

a. Rangking Tiap Alternatif

TOPSIS membutuhkan ranking kinerja setiap alternatif $\mathrm{Ai}$ pada setiap kriteria $\mathrm{Cj}$ yang ternormalisasi yaitu :

$r_{i j}=\frac{x_{i j}}{\sqrt{\sum_{i-1}^{m} x_{i j}^{2}}}$

dengan $i=1,2, \ldots . . m$; dan $j=1,2, \ldots \ldots . n$.

b. Matriks keputusan ternormalisasi terbobot

$y_{i j}=w_{i} r_{i j}$

Dengan $i=1,2, \ldots, m ;$ dan $j=1,2, \ldots, n$

c. Solusi Ideal Positif Dan Negatif

Solusi ideal positif $\mathrm{A}+$ dan solusi ideal negatif A- dapat ditentukan berdasarkan ranking bobot ternormalisasi (yij) sebagai berikut :

$A^{+}=\left(y_{1}^{+}, y_{2}^{+}, \ldots, y_{n}^{+}\right)$

$A^{-}=\left(y_{1}^{-}, y_{2}^{-}, \ldots, y_{n}^{-}\right)$

dengan

$y_{j}^{+}=$

$\left\{\max _{i} j_{i j} ; j i k a j\right.$ adalah atribut keuntungan

$\left\{\min _{i} j_{i j} ; j i k a j\right.$ adalah atribut biaya

$$
y_{j}^{-}=
$$

$\min _{i} j_{i j} ; j i k a j$ adalah atribut keuntungan

$\left\{\max _{i} j_{i j} ; j i k a j\right.$ adalah atribut biaya

$$
\mathrm{j}=1,2, \ldots, \mathrm{n}
$$

d. Jarak Dengan Solusi Ideal

Jarak antara alternatif $A_{i}$ dengan solusi ideal positif dirumuskan sebagai:

$D_{i}^{+}=\sqrt{\sum_{j=1}^{n}\left(y_{i}^{+}-y_{i j}\right)^{2}}$

Dengan $\mathrm{i}=1,2, \ldots, \mathrm{m}$

Jarak antara alternatif $A_{i}$ dengan solusi ideal negatif dirumuskan sebagai:
$D_{i}^{-}=$

$\sqrt{\sum_{j=1}^{n}\left(y_{i j}-y_{i}^{-}\right)^{2}}$ dengan $\mathrm{i}=1,2, \ldots, \mathrm{m}$

e. Nilai Preferensi Untuk Setiap Alternatif

Nilai preferensi untuk setiap alternatif (Vi) diberikan sebagai :

$V_{i}=\frac{D_{i}^{-}}{D_{i}^{-}+D_{i}^{+}}$

Dengan $\mathrm{i}=1,2, \ldots, \mathrm{m}$

Nilai Vi yang lebih besar menunjukkan bahwa alternatif Ai lebih dipilih.

\section{Analisa dan Perancangan \\ 3.1 Gambaran Sistem}

Gambaran sistem yangyang terjadi pada Sistem Pendukung Keputusan Seleksi Kelas Unggulan akan ditunjukan pada Gambar 1.

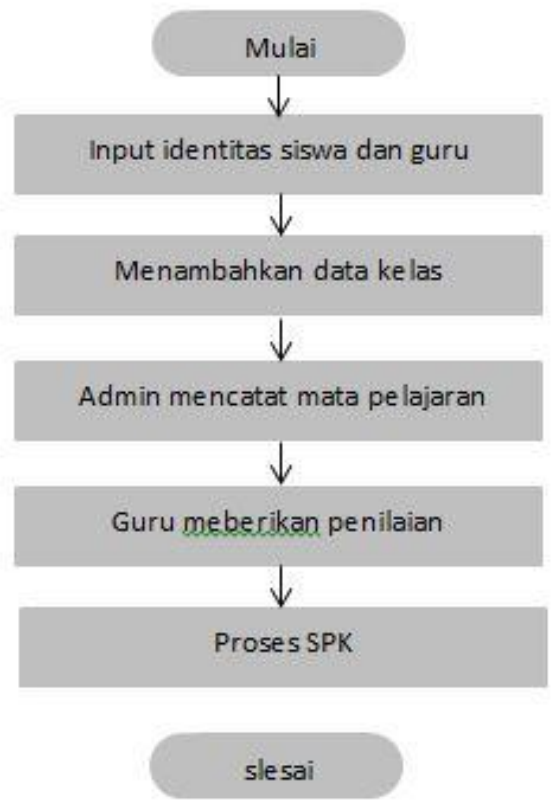

Gambar 1. Gambaran Sistem SPK Tanaman Obat

\subsection{Data Alternatif Dari Seleksi Kelas Unggulan}

Data yang diuji adalah 30 sampel yang setiap Pada Multi Criteria Decision Making (MCDM) alternatif adalah obyek-obyek yang berbeda dan memiliki kesempatan yang sama untuk dipilih oleh pengambil keputusan (Kusumadewi, 2006). Alternatif yang digunakan dalam sistem ini adalah siswa dari seluruh siswa di kelas tujuh.

\subsection{Data Kriteria dan Rating Penilaian}

Dari hasil observasi dan wawancara di SMP Negeri 7 Malang untuk evaluasi dokumen seleksi siswa kelas unggulan kriteria dan cara 
penilaiananya bersifat tetap. Kriteria dan cara peniliannya adalah sebagai berikut :

Tabel 4. Rating Kecocokan Antar Kriteria

\begin{tabular}{|l|l|}
\hline \multicolumn{1}{|c|}{ Kriteria Utama } & \multicolumn{1}{c|}{ Sub Kriteria } \\
\hline Nilai Akademik & Bahasa Indonesia \\
\cline { 2 - 2 } & Bahasa Inggris \\
\cline { 2 - 2 } & Matematika \\
\cline { 2 - 2 } & IPA \\
\cline { 2 - 2 } & Pelajaran Umum \\
\hline Prestasi & \\
\hline Sanksi & \\
\hline Absensi & \\
\hline Nilai Intelektual & \\
\hline Nilai Kepribadian & \\
\hline
\end{tabular}

3.4 Cara Penilaian Dari Setiap Kriteria

\begin{tabular}{|c|c|c|}
\hline No & Nama Kriteria & Cara Penilaian \\
\hline 1 & Bahasa Indonesia & $\begin{array}{l}\text { Untuk mata pelajaran } \\
\text { bahasa indonesia } \\
\text { cara penilaiannya } \\
\text { dengan cara input } \\
\text { nilai siswa mata } \\
\text { pelajaran bahasa } \\
\text { inggris di semester } \\
\text { genap, skala nilai } 1 \\
\text { sampai } 4\end{array}$ \\
\hline 2 & Bahasa Inggris & $\begin{array}{l}\text { Untuk mata pelajaran } \\
\text { bahasa inggris cara } \\
\text { penilaiannya dengan } \\
\text { cara input nilai siswa } \\
\text { mata pelajaran } \\
\text { bahasa inggris di } \\
\text { semester genap, skala } \\
\text { nilai } 1 \text { sampai } 4\end{array}$ \\
\hline 3 & Matematika & $\begin{array}{l}\text { Untuk mata pelajaran } \\
\text { Matematika cara } \\
\text { penilaiannya dengan } \\
\text { cara input nilai siswa } \\
\text { mata pelajaran } \\
\text { matematika di } \\
\text { semester genap, skala } \\
\text { nilai } 1 \text { sampai } 4\end{array}$ \\
\hline 4 & IPA & $\begin{array}{l}\text { Untuk mata pelajaran } \\
\text { IPA cara } \\
\text { penilaiannya dengan } \\
\text { cara input nilai siswa } \\
\text { mata pelajaran IPA } \\
\text { di semester genap, } \\
\text { skala nilai } 1 \text { sampai } 4\end{array}$ \\
\hline 5 & Prestasi & $\begin{array}{l}\text { Sangat Baik = 4 } \\
\text { Baik }=3 \\
\text { Cukup }=2 \\
\text { Kurang }=1\end{array}$ \\
\hline 6 & Sanksi & $\begin{array}{l}\text { Point } 0=4 \\
\text { Point } 5-50=3 \\
\text { Point } 51-75=2\end{array}$ \\
\hline
\end{tabular}

\begin{tabular}{|l|l|l|}
\hline & & Point 76-99=1 \\
\hline 7 & Absensi & $\begin{array}{l}\text { Pada kriteria absensi } \\
\text { nilai yang diinputkan } \\
\text { adalah jumlah alfa } \\
\text { (tanpa keterangan) }\end{array}$ \\
\hline 8 & Nilai Intelektual & $\begin{array}{l}\text { Sangat Baik=4 } \\
\text { Baik }=3 \\
\text { Cukup }=2 \\
\text { Kurang }=1\end{array}$ \\
\hline 9 & Nilai Kepribadian & Sangat Baik=4 \\
& & $\begin{array}{l}\text { Baik }=3 \\
\text { Cukup }=2 \\
\text { Kurang }=1\end{array}$ \\
& &
\end{tabular}

\section{Implementasi}

\subsection{Implementasi Basis Data}

Basis data yang diperlukan dalam sistem inidiberi nama 'db_akademik' seperti Gambar 2.

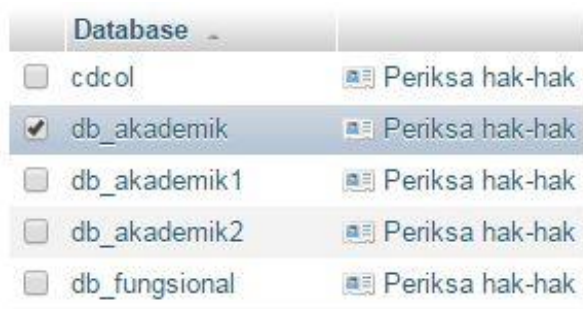

Gambar 2. Implementasi Basis Data

\subsection{Implementasi Antarmuka}

Perancangan yang telah dibuat, akan diimplementasikan kedalam aplikasi sistem pendukung keputusan. Menu Login dapat ditunjukkan pada Gambar 3.

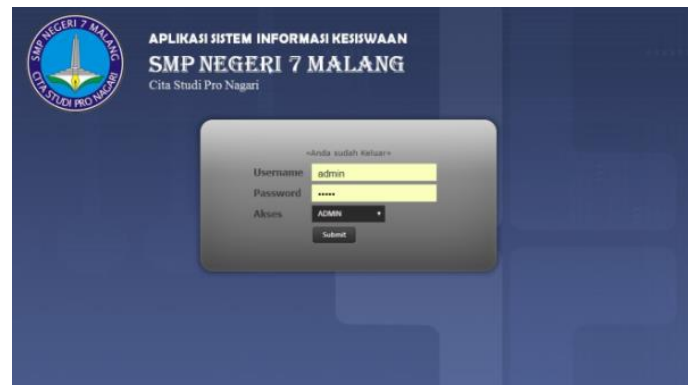

Gambar 3. Halaman Login

Data siswa adalah data untuk menyimpn data identita seluruh siswa kelas tujuh yang akan ditunjukkan pada Gambar 4. 


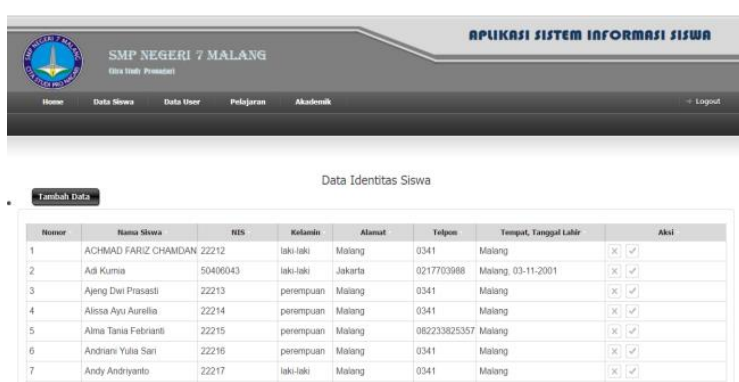

Gambar 4. Halaman Data Siswa

Halaman siswa dari data siswa perkelas untuk melakukan penilaian sesuai nilai kriteria yang ada dapat dilihat pada Gambar 5.

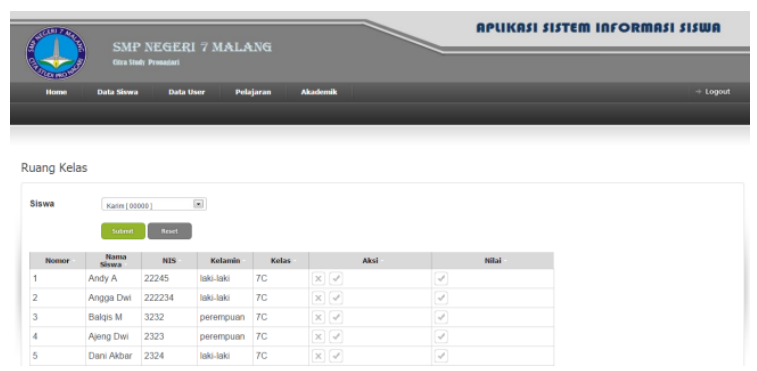

Gambar 5. Halaman Kelas

\section{Uji Coba dan Pembahasan}

5.1 Uji Coba

Berikut adala hasil penghitungan manual seleksi kelas unggulan dari exel.

5.1.1 Hasil Penghitungan sub Kriteria

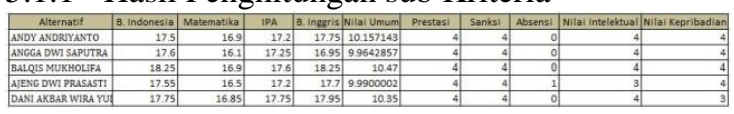

Gambar 5.1 Sub Kriteria

\subsubsection{Hasil Nilalai X}

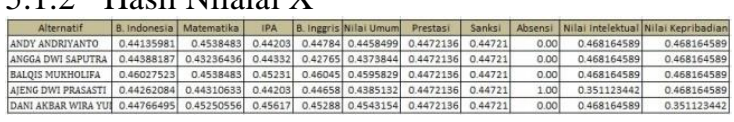

Gambar 5.2 Nilai X

5.1.3 Normalisasi Matriks

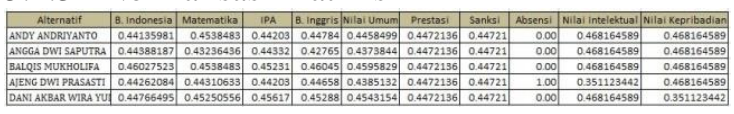

Gambar 5.3 Normalisai Matriks

\subsubsection{Matriks Terbobot}

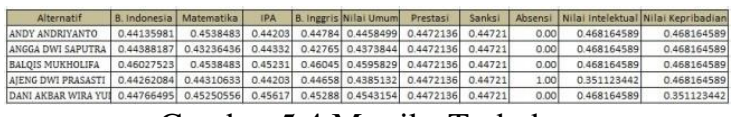

Gambar 5.4 Matriks Terbobot

5.1.5 Matriks Solusi Edeal Positif

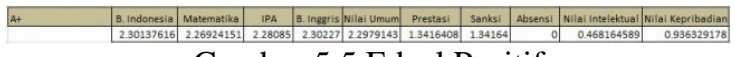

Gambar 5.5 Edeal Positif

5.1.6 Matriks Solusi Edeal Negatif

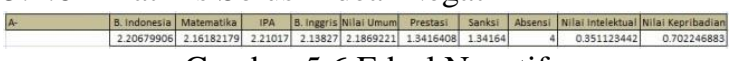

Gambar 5.6 Edeal Negatif
5.1.7 Solusi Positif Negatif Antar Alternatif

\begin{tabular}{|l|c|c|}
\hline \multicolumn{1}{|c|}{ Alternatif } & D + & D- \\
\hline ANDY ANDRIYANTO & 0.15044 & 4.01148 \\
\hline ANGGA DWI SAPUTRA & 0.24819 & 4.00858 \\
\hline BALQIS MUKHOLIFA & 0.01927 & 4.01632 \\
\hline AJENG DWI PRASASTI & 4.00566 & 0.25827 \\
\hline DANI AKBAR WIRA YUD & 0.24686 & 4.00661 \\
\hline
\end{tabular}

Gambar 5.7 Positif Negatif Antar Alternatif

5.1.8 Nilai Preferensi

\begin{tabular}{|l|l|}
\hline Alternatif & $\mathrm{v}$ \\
\hline ANDY ANDRIYANTO & 0.96385 \\
\hline ANGGA DWI SAPUTRA & 0.94169 \\
\hline BALQIS MUKHOLIFA & 0.99522 \\
\hline AJENG DWI PRASASTI & 0.06057 \\
\hline DANI AKBAR WIRA YUD & 0.94196 \\
\hline
\end{tabular}

Gambar 5.8 Nilai Preferensi

\subsection{Pembahasan}

Setelah dilakukan uji coba perhitungan dan dilakukan perbandingan hasil maka hasil kinerja SPK tersebut mendapatkan nilai akurasi mendekati $100 \%$ perbandingan dari antar alternatif pada Gambar6.

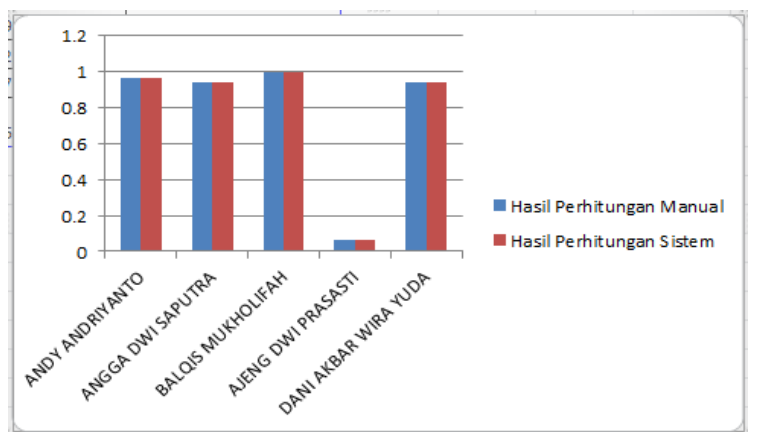

Gambar 6. Hasil Akurasi Penyakit Hipertensi

\section{Kesimpulan dan Saran \\ 6.1 Kesimpulan}

Berdasarkan penelitian yang telah dilaksakana oleh penulis pada skripsi ini yang berjudul Sistem Pendukung Keputusan Seleksi Siswa Kelas Unggulan Di SMP Negeri 7 Malang, dapat ditarik kesimpulan sebagai berikut :

a. Dengan nilai kriteria dari setiap alternatif yang berbeda dan dari bobot setiap kriteria yang berbeda maka maka diperoleh suatu hasil nilai perbandingan dari alternatif yang ada yang dapat dirangking dan mendapatkan nilai dari yang tertinggi hingga yang terendah .

b. SPK dalam seleksi kelas unggulan menggunakan metode TOPSIS ini telah berhasil dalam membantu para guru untuk memberikan hasil seleksi siswa 
kelas unggulan di SMP Negeri 7 malang.

\subsection{Saran}

Dalam penelitian ini menggunakan metode TOPSI, diharapakan untuk bisa dikembangkan di metode lain dengan kriteria yang berbeda yang lebih spesifik, disarankan untuk penelitian selanjutnya pada sistem ditambah fitur yang dapat mendukung dan mempermudah pengggunanya.

\section{Daftar Pustaka:}

Koko , Adi. 2014. Sistem Pendukung Keputusan Untuk Menentukan Siswa Kelas Unggulan Pada Smp Negeri 3 Tanjung Morawa Dengan Menggunakan Metode Weighted Product.

Munandar, Aris Tito. 2014. Sistem Pendukung Keputusan Pemilihan Siswa Kelas Unggulan Pada Sma Negeri 1 Sei Rampah Menggunakan Metode Topsis. Medan. Program Studi Teknik Informatika, STMIK Budidarma.

Murnawan. Siddiq, Fadjar Akhmad. 2012. Sistem Pendukung Keputusan Menggunakan Metode Technique for Order by Similarity to Ideal Solution (TOPSIS)

Nugroho, Sulistyo, Ardy. Himawan, Heribertus. Sistem Pendukung Keputusan Pemilihan Siswa Terbaik Untuk Kelas Unggulan Di Smp Negeri 6 Semarang Menggunakan Metode Promethee (Preference Ranking Organization Method For Enrichment Of Evaluations).

Riadi, Muchlisin., 2013. Pengertian Sistem Pendukung Keputusan. [Online] Tersedia: http://www.kajianpustaka.com/2013/09/sistem -pendukung-keputusan-spk.html [24November 2013] 